\title{
Semantic (Ir)regularities in Action Nouns in Irish
}

\author{
Maria Bloch-Trojnar
}

\section{Introduction}

Cross-linguistically, verbal nominalizations display a close semantic and syntactic affinity to their corresponding predicates (Comrie 1976; Comrie and Thompson 1985; Koptjevskaja-Tamm 1993), as obtaining between (1a) and (1b):

(1)
a. The professor examined the students.
b. the examination of the students by the professor

Nouns derived from verbs are most readily associated with the interpretation of "an action or process" (Comrie 1976:178), which regularly characterizes nominals related to dynamic verbs. When stative verbs act as the base, the derived nominal will denote a state (Melloni 2011:2), and we will observe that the same thematic relations obtain between the verb and the noun with respect to the thematic roles borne by their syntactic satellites (Rozwadowska 1997).

(2)
a. John loves Lucy.
b. John's love of Lucy

Another characteristic feature of action nominalizations is that they exhibit the process/result dichotomy: ${ }^{1}$

(3)
a. The examination was on the table.
b. She was his first love.

1. Anderson (1984) introduces the distinction between concrete and abstract nouns, Malicka-Klepars-ka (1988) regular nominalizations and lexicalizations, and Walińska de Hackbeil (1984) clausal nominals with a full $\Theta$-grid and $\Theta$-nominals. Grimshaw (1990) distinguishes between Complex Event Nominals, with an associated argument structure, and Simple Event or Result Nominals, which lack it. The basis for this classification is, among other things, their ability to take obligatory arguments, to license event-related PPs and to pluralize. This distinction is upheld in other frameworks as Argument-Structure Nominals (AS-Nominals) and Referential Nominals (R-Nominals) in Borer (2003), whereas Alexiadou (2001) refers to them as "process nominals" and "result nominals" respectively. 
The nominals in (3) denote concrete entities (a result in (3a), a person in (3b)), lack aspectual characteristics and accompanying satellite phrases, and cannot be directly associated with the thematic roles of Agent and Theme or Experiencer and Source borne by the corresponding verbs. They are also count nouns. The linguistic debate concerning nominalizations focuses on nouns with transpositional or situation-denoting semantics, whereas the result or referential nominals are largely an uncharted area. The aim of this paper is to examine the range of semantic interpretations displayed by verbal nouns in Irish.

In the process of lexicalization, the meanings of nominals drift away from the core Action/Event/State reading and come to denote "something material connected with the verbal idea (agent, instrument, belongings, place or the like)" (Marchand 1969: 303). According to Kastovsky (1986: 596), additional readings of derived nominals develop in accordance with the following hierarchy: "Action/Fact $\rightarrow$ Result $\rightarrow$ Locative $\rightarrow$ Instrument $\rightarrow$ Agent”. Malicka-Kleparska (1988) views lexicalization as the absorption or incorporation into the meaning of a given nominalization of the thematic role which is most object-like, i.e. Experienced, Causer, Instrument, Location, Source, Goal and, if none of these is available, that of Theme. Recently, we have witnessed the rise of more elaborate models of semantic interpretation, which tackle the vagueness of the theta role system, such as Pustejovsky's (1995) Generative Lexicon or Lieber's (2004) Decompositional Lexical Semantics. The machinery of both these models has been deployed by Melloni (2011) to pinpoint the constraints on the formation of entity-denoting deverbal nominals in Italian. She also hypothesizes that similar, though not entirely matching, patterns of polysemy can be observed in different languages. Her hypothesis will be put to the test with a view to establishing the range of non-eventive semantic interpretations displayed by verbal nouns in Irish. In section 2 I sketch the theoretical background for an empirical and comparative analysis to be developed in section 3. The scope of research ranges from verbal nouns formed by means of overt nominalizers to verbal nouns formed by means of conversion. The primary source of data is the most comprehensive Irish-English dictionary, i.e. Ó Dónaill (1977), containing about 2300 verbal entries. For more examples we also consult the online version of de Bhaldraithe (1959) and sporadically the New English-Irish Dictionary, recently launched by Foras na Gaeilge.

2. All three dictionaries are available at http://www.focloir.ie/en/ [last accessed 09.02.2017]. 


\section{Classification of referential nominals ( $R$-nominals)}

Non-eventive nominals lacking an associated argument structure typically denote the product or result of the event denoted by the base verb (e.g. construction in the sense of 'edifice'). However, they can exhibit a varied mix of readings which do not match up with this description. For example, administration refers to a group of people and obstruction is more likely to be viewed as the causer/means, while drink clearly has an object interpretation. Therefore, in this paper, following Borer (2003), we will use the term $\mathrm{R}$-nominals in the sense of referential rather than result nominals.

We will primarily focus on cases of logical/inherent polysemy in deverbal nouns, along the lines proposed by Pustejovsky (1995). However, polysemy can also result from paradigmatic sense extension or metonymic transfer. In addition to this, some interpretations of E-nominals, though not strictly actional (such as factual, temporal, manner), stem from the vagueness or underdetermination of eventive nominals and arise in the syntactic-pragmatic context. Yet another class of readings are lexicalized/ idiomatized senses, i.e. products of unpredictable semantic drift.

\subsection{Context-dependent readings (manner, temporal and factual, etc.)}

Some readings of action nouns are not instances of actual polysemy; i.e. they do not arise in the lexicon but on a higher level of syntactic-semantic composition. They result from the vagueness of the nominals and depend on a specific predicative context (or container into which they are inserted, as first observed by Vendler (1967) and later confirmed by Langacker (1991) and Pustejovsky (1995)). Action nominalizations can profile various facets of the reified event, such as the manner in which the action is carried out (4a), its duration (4b), its propriety (4c) and its factuality (4d), after Langacker (1991:32):

(4)
a. Harvey's taunting of the bear was merciless.
b. Harvey's taunting of the bear lasted three hours.
c. Harvey's taunting of the bear was ill-advised.
$\mathrm{d}$. Harvey's taunting of the bear came as a big surprise.

The examples above indicate that derived nominals can be accompanied by event participants on these interpretations, their presence being indicative of the regular status of the nominalization. Hence, they should be regarded as sense extensions of action nominals. 
Although extremely frequent in cross-linguistic terms, the factual interpretation of action nouns seems to be unattested in Irish. Doyle (2002:101) observes that when verbal nouns (VNs) are used as ordinary nouns, they are hardly ever accompanied by a complement, and he provides an example which, in his opinion, borders on ungrammaticality:

(5)

$\begin{array}{lllll}* & \text { Chuir } \text { ? } & \text { na gcloch } & \text { ionadh } & \text { orm. } \\ \text { put-past break-VN the stones-gen. } & \text { surprise on-me } \\ & \end{array}$

Notably, the superordinate predicate selected by Doyle (2002), i.e. surprise, triggers a factual interpretation. Searches for translations of 'the fact that' interpretations in Irish invariably return dependent clause renderings, e.g.

(6)
a. His appointment as captain surprised us.
Bhi iontas orainn cionn is go ndearnadh captaen de.
Bhi iontas orainn gur ceapadh é mar chaptaen.
b. I was surprised by her admission that she was ill.
Chuir sé iontas orm nuair a dúirt si go raibh sí tinn.
c. I was surprised at his late arrival.
Bhí iontas orm go raibh sé déanach ag teacht.

Another context-dependent interpretation which seems to be virtually unattested with Irish verbal nouns is temporal. In many languages an action noun can denote the time span that it covers, especially when preceded by temporal extent expressions such as during, e.g. during the construction of the house. Again, attempts at extracting nominals with a temporal denotation from the dictionaries predominantly yield clausal equivalents (7c). Cases where the noun retains an actional interpretation are very rare (7a). I have found one such example in de Bhaldraithe (1959), and there are a few more such present-day cases as evidenced by the data from the New English-Irish Dictionary. Complex prepositions referring to duration, such as le linn, $i$ rith and $i$ gcaitheamh, can precede lexicalized verbal nouns which are like ordinary nouns (7b). 
(7)

a. 'during the process of dismantling it' le linn a bhainte anuas (de Bhaildraithe 1959)

'during the equipment of the building' le linn fheistiu an fhoirgnimh

'during take-off and landing' le linn an éiri de thalamh agus na tuirlingthe

'during the mixing of ingredients' le linn mheascadh na gcombábhar

b. 'in the course of the meeting' i gcaitheamh an chruinnithe (de Bhaildraithe 1959)

'the rock was faulted during the earthquake' éascadh an charraig le linn an chreatha talin

'silence must be maintained during the examination' ní mór fanacht ciúin i rith an

scrúdaithe

c. 'during the fitting of the locks' nuair a bhi na glais á bhfeistiú

'I'll talk to you during the break' labhróidh mé leat nuair a bheidh an briseadh ann,

labhróidh mé leat le linn an tsosa

'during the clearance of debris' nuair a bhi an bruscar á ghlanadh ar shiúl

'during his convalescence from the illness' agus é ag teacht chuige féin ón tinneas,

le linn dó bheith ag teacht chuige féin ón tinneas

'during his stay at the farm' le linn dó bheith ag fanacht ar an bhfeirm

On the other hand, action nouns in Irish freely show the manner interpretation, as can be seen in examples in (8) below, taken from Ó Dónaill (1977):

(8)

a. Tá siúl direach aige.

'manner of walking, gait'

He walks straight.

b. Níl gearradh ná déanamh ar na cultacha aige. 'style of cutting'

His suits are neither well cut nor

well made.

c. Is olc an fhéachaint atá air.

He looks bad.

'the way one looks, appearance'

d. Is olc an üsaid a thug siad don leanbh.

'manner of handling, treatment'

They badly mistreated the child.

e. Is deas an scriobh atá aige.

'(hand-)writing’

He writes a nice hand.

An interesting property of action nouns in Irish is the ability reading. Whereas in other languages this interpretation can be observed in nominals related to stative verbs only, in Irish it can be also observed with nouns derived from verbs relating to dynamic situations. Such verbal nouns denote the potential or the ability to perform an action. The examples in (9) come from Ó Dónaill (1977): 
(9)
a. Tá ambarc maith agam. 'I have a good sight.'
b. Tá éisteacht mhaith aige. 'He has a good sense of hearing.'
c. Tá déanamh gnó ann. 'He is well able to transact business, to manage.'
d. Nil tarraingt na gcos ann. 'He can hardly drag his feet along.'
e. Níl léamb ná scriobh aige. 'He can neither read nor write.'

\subsection{Sense extensions}

Melloni (2011) discusses Agentive-Collective and Locative sense extensions. The nominal amministrazione 'administration', just like its Polish equivalent, can denote a group of people or an institution involved in the performance of administrative activities and can refer to the place where such activities are carried out. Action nouns can show only the additional locative interpretation, as in entrata 'entrance'. The collective reading can also be extended to nouns that refer to different systems, plants or instruments, such as riscaldamento 'heating', illuminazione 'lighting'. Such sense extensions are possible if the morphological system lacks other means of expressing the collective/ locative senses in deverbal word formation (see "paradigmatic extensions under pragmatic pressure" in Booij \& Lieber 2004).

I have not come across cases where action nouns show collective sense extensions which would refer to animate entities (cf. téamh lárnach 'central heating', soilsiú sráide 'street lighting'), unlike locative senses, which are exemplified in (10) below:

(10)

\section{Verb}

réitigh 'level, smooth'

doirt 'pour, spill, shed'

snámb 'swim, float'

léim 'jump, fly up'

\section{Nominalization with a locative sense}

réiteach 'clearing, level space'

réiteach i gcoill 'forest clearing'

réiteach agus sliabh 'plain and mountains'

doirteadh 'watershed, slope'

snámh 'swimming-place'; 'deep pool'; 'deep water, sea'

snámb abhann 'swimming-place (fish-pool in

river)'

amuigh ar an snámb 'out in deep water'

Ná tit sa snámb. 'Don't fall into the deep.'

léim 'chasm, promontory' 
cart 'clear away'

luigh 'lie' cartadh 'dump'

lui 'lie, slope, slant'

lui an chnoic, 'the lie of the hill'

lui an chósta 'the lie of the coast'

lui na tire 'the lie of the land'

\subsection{Lexicalized senses}

Cases of regular polysemy have to be teased apart from lexicalized senses. According to Beard (1987) "semantic drift" affects stored items in both principled and random ways. Semantic irregularity may be the offshoot of evolution from primary transparent meanings (e.g. construction, painting), or an idiomatic meaning may be added to the output of a regular process (e.g. revolution, transmission 'gearbox'). ${ }^{3}$

Verbal nouns listed in (11) have disengaged from the word formation rule which generated them and so show an idiosyncratic non-actional interpretation:

(11)

\begin{tabular}{ll}
\multicolumn{1}{c}{ Verb-VN } & \multicolumn{1}{c}{ Nominalization (plural) } \\
imigh 'go, go on'-imeacht & imeachtai an lae 'events of the day' \\
buail 'hit' - bualadh & bualaí cloiche 'bruises from stones on the feet' \\
bris 'break'- briseadh & bristeacha 'breakers (waves)' \\
sáigh 'thrust, stab'-sá & $\begin{array}{l}\text { sá 'stake' } \\
\text { sáite ciseáin 'stakes of basket' } \\
\text { oscail 'open'- oscailt }\end{array}$
\end{tabular}

3. In the automotive sense transmission cannot have evolved slowly from the primary, transparent meaning 'process of transmitting'. Carstairs-McCarthy (1992:185) explains that "there is nothing in either the derivation itself or our experience of the world which might tell us that it relates to the transmission of power from the engine to the wheels in cars, rather than (say) the transmission of a message from the speaker to the hearer in a telephone conversation (whereby transmission might mean 'handset'), or the transmission of an inherited characteristic from one generation to another (whereby transmission might mean 'gene')." Thus, the application of this term to a particular referent is the result of a conscious choice of a speaker and its subsequent institutionalization. 


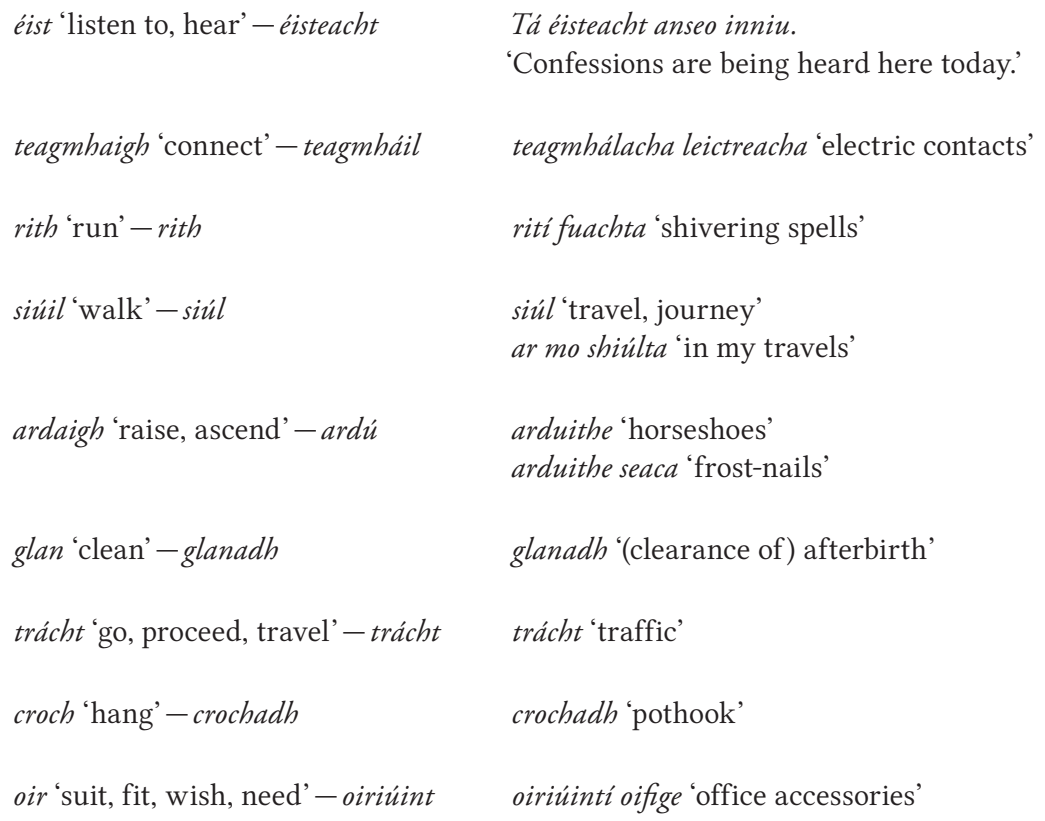

Apart from non-actional semantics, the count status of the noun may be an indicator of its lexicalized status; i.e. not all count deverbal nouns show unpredictable, idiomatized senses (see section 3 below).

\subsection{Core readings}

In this analysis we are primarily interested in cases of logical/complementary polysemy, as put forward in Pustejovsky \& Anick (1988) and Pustejovsky $(1995,2005)$. Logical or complementary polysemy can characterize both simplex and morphologically complex items. It refers to situations where a given lexeme has systematically related senses, which can be focused in distinct environments without being mutually exclusive $(12 \mathrm{a}-\mathrm{b})$ and which can cluster together, producing the so-called dot-object, which allows a less specific, generic interpretation, as illustrated in (12c):
a. Mary enjoyed the book.
('information object')
b. The book has a red cover.
('physical object')
c. Mary likes the book.
('physical object.information object') 
Pustejovsky (1995) argues that the semantics of action nouns in English is a reflection of the sub-events composing the event structure of the verb. An accomplishment verb, which is a left-headed transition, will lexicalize two sub-events, i.e. process and resulting state. The additional sense generated in the lexicon (i.e. dot-object reading) is an event reading, as represented in (13a) below (Pustejovsky 1995: 170-71):
a. The house's construction was finished in two months.
(process.result (event))
b. The construction was interrupted during the rains.
(process)
c. The construction is standing on the next street.
(result)

The result interpretation of nominals derived from verbs of creation may refer to the resulting state or the object created, i.e. the individual artefact resulting from the process (Pustejovsky 1995:172). ${ }^{4}$ The nominal purchase derived from an achievement verb, which is a right-headed transition focusing the result state and not the process leading up to it, will show the event-object polysemy.

Product or result nominals form the core of denotations of R-nominals. Pustejovsky's proposal that the semantics of R-nominals reflects the aspectual properties of base verbs is pursued further in Melloni's (2011) analysis, where the core semantics of R-nominals encompasses the PRODUCT, MEANS and ENTITY IN STATE readings, where ENTITY IN STATE can be viewed as a macro-category, since it captures the state element of meaning shared by all of them. The macro-category of ENTITY IN STATE is available to states and transitions, in Pustejovsky's classification (Melloni 2011:183). The PATH and MEASURE interpretations are also closely linked to the aspectual properties of base verbs.

\footnotetext{
4. A more detailed discussion of the polysemy characterizing process-result nominals such as construction, translation or development is offered in Melloni (2011) and Melloni \& Ježek (fc.). The (result-)state interpretation is available for verbs which express the process and the state, e.g. isolation. It is not available for creation verbs and redescription verbs, e.g. construction, translation. Such nouns cannot refer to the state of being constructed or translated. Instead, they denote concrete or abstract objects. Therefore, their inherent polysemy should be more appropriately classified as event.(result-)object rather than process.(result-)state. In this analysis, object and state readings will be regarded as the hyperonymic categories of result.
} 
The PRODUCT interpretation is prototypically associated with result nouns and refers to the entity or object coming into existence as a result of the process denoted by the base verb (construction, painting). ${ }^{5} \mathrm{R}$-nominals related to achievement verbs rivenimento 'finding/discovery', vincita 'win' and acquisizione 'acquisition', denote entities associated with the punctual/instantaneous changes of states. R-nominals can refer to objects or entities which play different roles in the situation denoted by the base predicate. The means interpretation, discussed by Bierwisch (1991), denotes the material/object used to perform the action:

\section{(14) Die Isolation des Kabels war defekt.}

The insulation of the cable was defective.

Melloni (2011:112) points out that the nominal can also denote the material/object resulting from the action (otturazione 'a tooth filling', argenatura 'silver plating', decorazione 'decoration').

The nominals preferenza 'preference' and cognoscenza 'knowledge', related to unambiguously stative verbs preferire 'prefer' and conoscere 'know', denote the internal objects of base verbs. The R-nominal will refer to (animate/ inanimate) objects/entities associated with the states. With psychological verbs (which in aspectual terms can be causative/inchoative or stative), the R-nominal might refer to the entity/object corresponding to the SOURCE or STIMULUS of the psychological situation - to the exclusion of the Experiencer (e.g. sorpresa 'surprise').

PATH nominals are derived from verbs with a path component in their semantics (Jackendoff 1990) which lexically involve a scalar structure (Hay, Kennedy \& Levin 1999). Degree achievements (Dowty 1976) such as prolungare 'extend' and verbs of directed motion such as dicendere 'descend' give rise to nominals, which in addition to the product meaning, can refer to a spatial or directional path (prolungamento 'extension', discesa 'descent'). The underlying scalar structure can also be observed in MEASURE interpretations characterizing nominals derived from verbs with stative interpretations (apertura 'span').

R-nominals do not correspond to a fixed argument position within the verb's Argument Structure. It appears that all syntactic arguments can be

5. Product nominals can be subject to further semantic shifts, which can be also observed in the lexicon of simplex nouns. Just like book can be understood as a physical/concrete object and an 'information object', so can nominals related to verbs of writing and image creation activities. For example, translation can have an abstract information-object sense which is primary and a concrete one which is derived by metonymic transfer. 
bound in derivation: internal and external (corresponding to the subject and object positions) and adjuncts (expressing manner/temporal/measure modification) of the base verb. Since in some cases the R-nominal cannot be associated with a syntactic argument at all, as in e.g. traduzione 'translation', the minimal requirement is that the R-nominal should correspond to a participant in the Lexical Conceptual Structure (LCS) of the base verb.

Since not all transition predicates give rise to logically polysemous nominals, there must be additional lexical constraints. In the course of her analysis, Melloni (2011) establishes that the product interpretation depends on the presence of an effected participant in the LCS of the base verb; i.e. the verbs must denote a creation event. This event may be broadly understood as representation or modification/alteration of the object's referent. Effected arguments correspond to incremental arguments; i.e. their emergence is gradual and is mapped directly or indirectly onto the time course of the corresponding accomplishment event. Path interpretation in nominals depends on the presence of a non-effected incremental Path argument in the base verb. The formation of R-nominals in non-dynamic verbs depends on the presence of a non-sentient argument of the base; i.e. the R-nominal can refer to the non-Experiencer entity in a state (Melloni 2011:115-16). Since the product-oriented interpretation is available to nominals which are characterized by incrementality and effectedness, the following classes of verbs are ruled out as potential bases: state verbs; activity verbs, which lack a state component (administrare 'administrate'); directed motion verbs, describing situations that do not affect or modify the object that corresponds to a holistic Theme and implies a spatial path (salire 'climb'); accomplishment and achievement verbs with an affected Theme, which do not lead to the creation of new entities or modifications conceptualizable as creations (asciugare 'dry'); accomplishment and achievement verbs which involve the removal of the object (verbs of killing, verbs of removal and disappearance). ${ }^{6}$

We will now attempt to establish which aspects of verbal semantics are conducive to the emergence of R-nominals in Irish and how they affect the denotation of the nominal. We will discuss verbs belonging to various aspectual types and semantic classes to see whether the semantic generalizations formulated for Italian by Melloni also hold for Irish.

6. This would explain why there is an imbalance between E- and R-interpretations in that the former is the default denotation and the latter is not always available; e.g. the deverbal nominals such as abolizione 'abolition' or sfruttamento 'exploitation' have no R-interpretation. 


\section{Base verb semantics and the interpretation of $R$-nominals}

In this section we will pay special attention to various semantic classes of verbs which fall into the category of transitions, i.e. accomplishments and achievements in the Vendler-Dowty taxonomy, since they are supposed to give rise to PRODUCT and OBJECT nominals.

\subsection{Verbs of creation}

According to Melloni (2011:185) only creation verbs which express "the (potential) ability of putting into existence a new entity, i.e. the resulting product/artifact" can give rise to R-nominals with the product reading. Creation verbs subsume three subclasses of verbs, which predominantly are accomplishments with an incremental Theme or Path argument, along the lines proposed in Tenny (1994) and Dowty (1991). These are "Creation (/Result-Object) verbs" such as construire 'build', whose object is effected, not affected, changed or modified but created as a result of the action denoted by the base verb. "Creation by Representation" verbs such as tradurre "translate' give rise to an entity-denoting nominal which is a representation of the Source argument, typically mapped onto the direct object position. "Creation by Modification" verbs such as correggere 'correct' motivate nominals which denote a new entity besides the affected (Patient/Theme) object.

\subsubsection{Creation verbs}

Prototypical creation predicates denote events in which an Agent causes an entity to come into existence. Unlike Agent-Patient verbs, which also have an Agent in their theta grid, they do not take a Patient or affected object (wash a shirt, drive a car) but an effected object or object of result. Effected objects prototypically realize incremental Themes or Paths, i.e. those LCS participants which measure out or delimit the event described by the verb.

The R-nominals corresponding to these verbs typically denote effected entities of creation events. The Irish data corroborate this. The verb tóg 'build' will give rise to a noun with the regular actional interpretation, as in tógáil tithe, droichead 'construction of houses, of bridges' and an entity-denoting count noun tógáil 'structure', as in (15) below:

(15) Is breá na tógálacha iad.

They are fine structures. 
Some more examples are provided in Table 1 below: ${ }^{7}$

\section{Table 1. R-nominals with a product interpretation related to creation verbs}

\begin{tabular}{ll}
\multicolumn{1}{c}{ Verb } & Nominalization (plural) \\
tóg 'lift, raise, build' & tógáil 'structure, building' \\
táirg 'produce, manufacture' & táirgeadh, táirge 'product' \\
léirigh 'produce' & léiriù 'production' \\
grean 'engrave' & $\begin{array}{l}\text { greanadh 'engraving', } \\
\text { greanadh lineach 'line-engraving' }\end{array}$
\end{tabular}

However, they are outnumbered by nominalizations related to creation verbs, which do not give rise to entity-denoting nominals. These include, among others, déanamh 'do, make.VN', cruthú 'create.VN', foirgniú 'construct.VN', ceapadh, cumadh 'invent.VN', ullmhu' 'prepare.VN', seiftiú 'provide.VN' and inscriobh 'inscribe.VN'.

This may be so because the product interpretation is rendered by a derivative based on the action noun or the verbal root itself by means of some other suffix.

\begin{tabular}{ll}
\multicolumn{1}{c}{$\mathrm{V}-\mathrm{VN}$} & Nominalization with a specialized suffix \\
cruthaigh-cruthü 'create' & cruthüchán 'creation, thing created' \\
$\begin{array}{l}\text { foirgnigh-foirgniú } \\
\text { build, construct' }\end{array}$ & foirgneamh 'building, structure' \\
inscríobh-inscriobh 'inscribe' & $\begin{array}{l}\text { inscribhinn 'inscription' } \\
\text { Tá inscribhinn Laidine air. 'It bears a Latin } \\
\end{array}$ \\
& inscription.'
\end{tabular}

7. In this section we examine cases of regular polysemy, which means that for each nominalization the regular interpretation of Action/Event/State is accessible. Only the entity-denoting interpretation is provided in the gloss.

8. In order to save space, nouns which are confined to the action or event reading are glossed here as 'verb.VN'. 


\subsubsection{Creation verbs by representation}

Representation verbs denote a situation where a new object/entity is created 'besides' or 'in relation with' the existing one. The internal argument of such verbs denotes an already existing entity. The result does not correspond to the entity denoted by the verbal object. Their internal argument can be characterized thematically as a Source and it is neither affected nor effected by the event. They are representation-source themes (Dowty 1991).

Verbal nouns related to representation verbs which give rise to R-nominals are listed in Table 2 below.

\section{Table 2. R-nominals with a product interpretation related to verbs of creation by representation}

\begin{tabular}{|c|c|}
\hline Verb & Nominalization (plural) \\
\hline faisnéis 'relate, recount, narrate' & $\begin{array}{l}\text { faisnéis 'information, intelligence, report' } \\
\text { faisnéis na haimsire 'weather report' } \\
\text { faisnéisí trádála 'trade returns' }\end{array}$ \\
\hline aithris 'imitate, mimic, mock' & $\begin{array}{l}\text { aithris 'imitation' } \\
\text { Nil inti ach aithris. 'It is only a makeshift.' } \\
\text { Fainic aithrisi. 'Beware of imitations.' }\end{array}$ \\
\hline léirigh 'clarify, explain, illustrate' & $\begin{array}{l}\text { léiriú 'clarification, illustration, representation' } \\
\text { léiriú grafach 'graphical representation' }\end{array}$ \\
\hline luaigh 'mention, cite, quote' & $\begin{array}{l}\text { lua 'mention, citation, reference' } \\
\text { lua foinse 'reference to source' }\end{array}$ \\
\hline $\begin{array}{l}\text { deimhnigh 'certify, affirm, assure, } \\
\text { check' }\end{array}$ & $\begin{array}{l}\text { deimhniú 'certification, certificate' } \\
\text { deimhniú cáiliochta 'certificate of qualification' }\end{array}$ \\
\hline
\end{tabular}

Nominals derived from representation verbs and confined to the actional interpretation include, for example, aistriu' 'translate.VN', cóipeáil 'copy.VN', brionnú, falsú 'forge, falsify.VN', clóscriobh 'type. VN', canadh 'sing. $\mathrm{VN}$ ', péinteáil 'paint.VN', tarraingt 'pull.VN', liniu' 'draw.VN' and aithris 'narrate, recite. VN'. As in the case above, we may be dealing here with the phenomenon of blocking. The development of an entity denotation in action nouns is thwarted by the existence of a lexical item based on the same verbal stem with a concrete denotation or of a simplex noun which motivates the verb, e.g. 
(17)

\begin{tabular}{|c|c|}
\hline $\mathrm{V}-\mathrm{VN}$ & $\begin{array}{l}\text { Nominalization with a specialized suffix } \\
\text { /Simplex noun motivating the verb }\end{array}$ \\
\hline aistrigh-aistriü 'translate' & $\begin{array}{l}\text { aistriúchán ‘translation' } \\
\text { Is aistriúchán ó Spáinnis go Béarla é. } \\
\text { 'It’s a Spanish-English translation.' }\end{array}$ \\
\hline cóipeáil-cóipeáil 'copy' & cóip 'copy' \\
\hline brionnaigh-brionnú 'falsify, forge' & brionnúchán 'something that has been forged' \\
\hline clóscriobh-clóscriobh 'type' & clóscribhinn 'type-script' \\
\hline péinteáil-péinteáil 'paint' & $\begin{array}{l}\text { péintéireacht 'painting' } \\
\text { péintéireacht ola 'oil painting' }\end{array}$ \\
\hline linigh-liniú 'draw' & $\begin{array}{l}\text { liniocht '(line-)drawing' } \\
\text { liniocht phionsail 'pencil-drawing' }\end{array}$ \\
\hline
\end{tabular}

\subsubsection{Creation verbs by modification}

Modification verbs denote a situation where a tangible modification (involving the breaking, addition or subtraction of material) in the existing object takes place. The interpretation of the R-nominals corresponding to verbs which involve the addition of material is the MEANS interpretation (material used to carry out the action, which can also be understood as the concrete result or product of the action). Verbal nouns related to modification verbs which give rise to R-nominals are listed in Tables $3 \mathrm{a}-\mathrm{c}$ below.

\section{Table 3a. R-nominals with a product interpretation related to verbs of creation by modification}

\begin{tabular}{ll} 
Verb & \multicolumn{1}{c}{$\begin{array}{c}\text { Nominalization (plural) } \\
\text { ceartaigh 'correct, rectify, amend' }\end{array}$} \\
$\begin{array}{l}\text { ceartú 'correction, amendment, adjustment' } \\
\text { ceartúchán 'correction' } \\
\text { ceartúcháin a dhéanamh ar cheacht 'to make } \\
\text { corrections in a lesson' } \\
\text { ceartúcháin a dhéanamh ar scríbhinn 'to make } \\
\text { corrections in a written document' }\end{array}$ \\
athraigh 'change, alter' & $\begin{array}{l}\text { athrúchange, alteration' } \\
\text { athruithe ó bhun 'sweeping changes' }\end{array}$
\end{tabular}




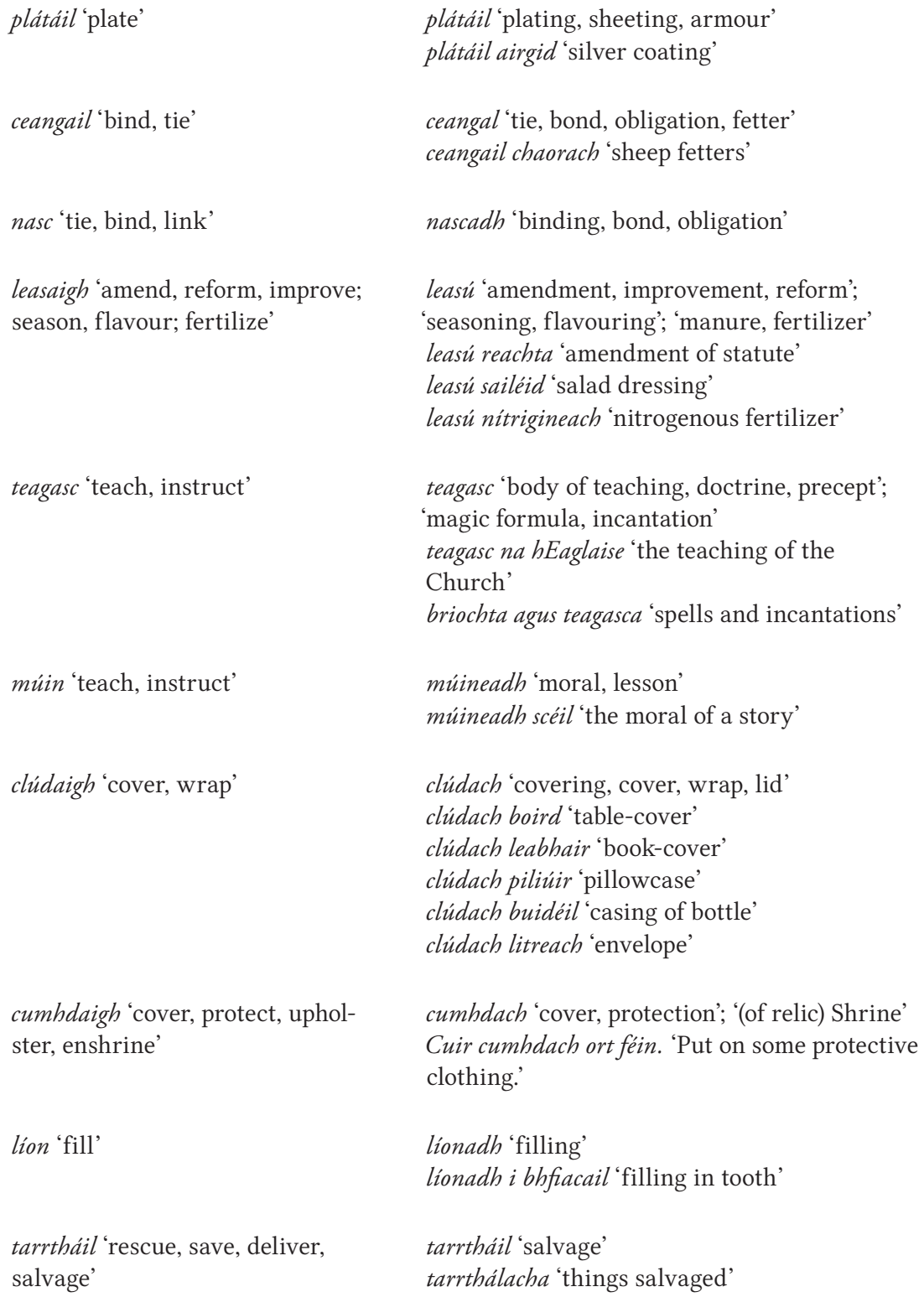

cumhdach 'cover, protection'; '(of relic) Shrine' Cuir cumbdach ort féin. 'Put on some protective clothing.'

lionadh 'filling'

lionadh i bhfiacail 'filling in tooth'

tarrtháil 'salvage'

tarrthálacha 'things salvaged'

Also, events which tangibly/physically modify the object are expected to give rise to product R-nominals, providing that they do not give rise to the creation or modification that could be interpreted as a new entity. This class subsumes degree achievements such as méadaigh 'enlarge' and giorraigh 'shorten' as opposed to triomaigh 'dry' and dirigh 'straighten'. 
Table 3b. R-nominals with a product interpretation related to verbs of creation by modification (degree achievements)

\begin{tabular}{|c|c|}
\hline Verb & Nominalization (plural) \\
\hline laghdaigh 'lessen, decrease, diminish' & laghdú 'decrease, diminution, reduction' \\
\hline gor 'heat, warm' & $\begin{array}{l}\text { goradh 'heating, warming, heat, warmth' } \\
\text { goradh dearg 'to raise iron to a red heat' } \\
\text { goradh geal 'to raise iron to a white heat' } \\
\text { goradh a thabhairt d'iarann 'to raise iron to } \\
\text { heat' }\end{array}$ \\
\hline $\begin{array}{l}\text { méadaigh 'increase, multiply, enlarge, } \\
\text { grow bigger' }\end{array}$ & $\begin{array}{l}\text { méadú 'increase, multiplication, } \\
\text { enlargement' } \\
\text { méadú ar shiopa 'extension to shop' } \\
\text { Is mór an méadú a tháinig air. 'He has grown } \\
\text { a lot.' }\end{array}$ \\
\hline giorraigh 'shorten’ & giorrú 'abbreviation' \\
\hline \multicolumn{2}{|c|}{$\begin{array}{l}\text { Nominals confined to the actional interpretation are in the majority and they } \\
\text { include: sciamhú, breathaigh 'beautify, embellish.VN', maisiú 'adorn, decorate. } \\
\text { VN', múnlú 'mould, shape.VN', feabhsú 'improve.VN', saibhriú 'enrich.VN', } \\
\text { bacadh 'balk, hinder.VN', leathnú 'widen, extend.VN', idirdhealú 'differentiate. } \\
\text { VN', claochlú 'deteriorate.VN', isliú 'lower.VN' and ardú 'raise, ascend.VN'. } \\
\text { Lexical items which block the emergence of the R-interpretation are given } \\
\text { in (18): }\end{array}$} \\
\hline
\end{tabular}

(18)

$\mathrm{V}-\mathrm{VN}$

maisigh-maisiú

'adorn, decorate, beautify'

feabhsaigh-feabhsú

'improve'

bac-bacadh 'balk, hinder'

\section{Nominalization with a specialized suffix/} Simplex noun motivating the verb

maisiúchán 'adornment, decoration' maisiucháin na Nollag 'Christmas decorations'

feabhas 'excellence, improvement' Tá feabhas ar an aimsir. 'The weather has turned fine.' feabhsúchán '(act of) improving, improvement' deimhniú feabhsúcháin 'improvement certificate'

bac 'balk, hindrance, barrier' 
Another subcategory within modification verbs consists of verbs like break, which is a pure change of state verb, and cut, which additionally contains the manner element. Importantly, these verbs create a change of state in the verbal object, a change which is associated with the creation of a new object/entity, a by-product of the event denoted by the verb. Other prominent classes with these characteristics include verbs of bending and tearing/ separating.

Table 3c. R-nominals with a product interpretation related to verbs of creation by modification (change of state verbs of breaking, separating, bending)

\begin{tabular}{|c|c|}
\hline Verb & Nominalization (plural) \\
\hline bris 'break' & $\begin{array}{l}\text { briseadh 'break'; 'change'; 'battle, defeat' } \\
\text { briseadh aife '(ruffle caused by) start of ebb-tic } \\
\text { briseadh airgid 'small change' } \\
\text { briseadh na Bóinne 'the defeat at the battle of } t \\
\text { Boyne' }\end{array}$ \\
\hline deighil 'divide, separate' & $\begin{array}{l}\text { deighilt 'division, partition, segmentation' } \\
\text { deighilt (a dhéanamh) idir dhaoine } \\
\text { 'to cause a split, a cleavage, between people' }\end{array}$ \\
\hline rois 'rip, rend' & $\begin{array}{l}\text { roiseadh 'rip, rent, tear'; 'ragged cutting' } \\
\text { roiseadh i stoca 'ravel in stocking' } \\
\text { roiseadh in éadach 'rent in cloth' } \\
\text { roiseadh i gcraiceann 'tear in skin' }\end{array}$ \\
\hline oscail 'open' & $\begin{array}{l}\text { oscailt 'opening' } \\
\text { oscailt idir charraigeacha 'an opening between } \\
\text { rocks' } \\
\text { oscailt súl 'eye-opener' }\end{array}$ \\
\hline fill 'bend, fold' & $\begin{array}{l}\text { filleadh 'bend, fold' } \\
\text { filleadh in éadach 'fold in cloth' }\end{array}$ \\
\hline feac 'bend' & $\begin{array}{l}\text { feacadh 'bend, bent posture' } \\
\text { feacadh } i \text { rud'a bend, a twist, in something' }\end{array}$ \\
\hline fiar 'bend, twist, distort' & fiaradh 'warping, distortion' \\
\hline
\end{tabular}


gearr 'cut, shorten, levy'

scor 'cut, slash' gearradh 'cutting, cut';

gearradh ar mhéar 'cut on finger'

gearradh i mbléin 'cut, incision, in groin'

gearradh rothai i mboithrin 'wheel-ruts in lane'

na gearrthacha a ioc 'to pay the rates'

Bhi na gearrthacha trom orainn. 'The rates were

a burden on us.'

scoradh 'cut, slash, gash'

scoradh claimh 'sword-cut'

This time the verbs which belong to the same classes and lack the entity-denoting interpretation in the nominal are in the minority, and they include réabadh 'tear, rend, shatter.VN', dealú, pl. dealuithe 'separate.VN' and ciorru' 'cut, hack, maim.VN'.

It has to be underlined that verbs of varied aspectual classes, such as accomplishments and achievements but also activity verbs which do not take incremental themes but affected objects, contrary to the prediction of Melloni (2011), can give rise to R-nominals. The product interpretation can arise any time our system of conceptual and pragmatic knowledge detects a causally related by-product or effect associated with the event denoted by the verb. This is so with verbs of damage (e.g. loit 'injure'), verbs of contact by impact (e.g. leadair 'strike') and verbs of exerting force (e.g. brúigh 'press') whose theta grid contains an Agent and Patient/Affected Object. The related R-nominals are fairly numerous and tend to denote the mark left on the Patient.

Table 4. R-nominals with a product interpretation related to verbs with Affected Objects (verbs of damage, verbs of contact by impact and verbs of exerting force)

\begin{tabular}{ll}
\multicolumn{1}{c}{ Verb } & \multicolumn{1}{c}{ Nominalization (plural) } \\
\hline loit 'injure' & $\begin{array}{l}\text { lot 'hurt, wound, damage, violation, breach' } \\
\text { lot aithne 'breach of commandment' } \\
\text { lot rialach 'breach of rule' }\end{array}$ \\
goin 'wound, stab' & $\begin{array}{l}\text { goin 'wound, stab' } \\
\text { goin bháis 'death-wound' }\end{array}$
\end{tabular}




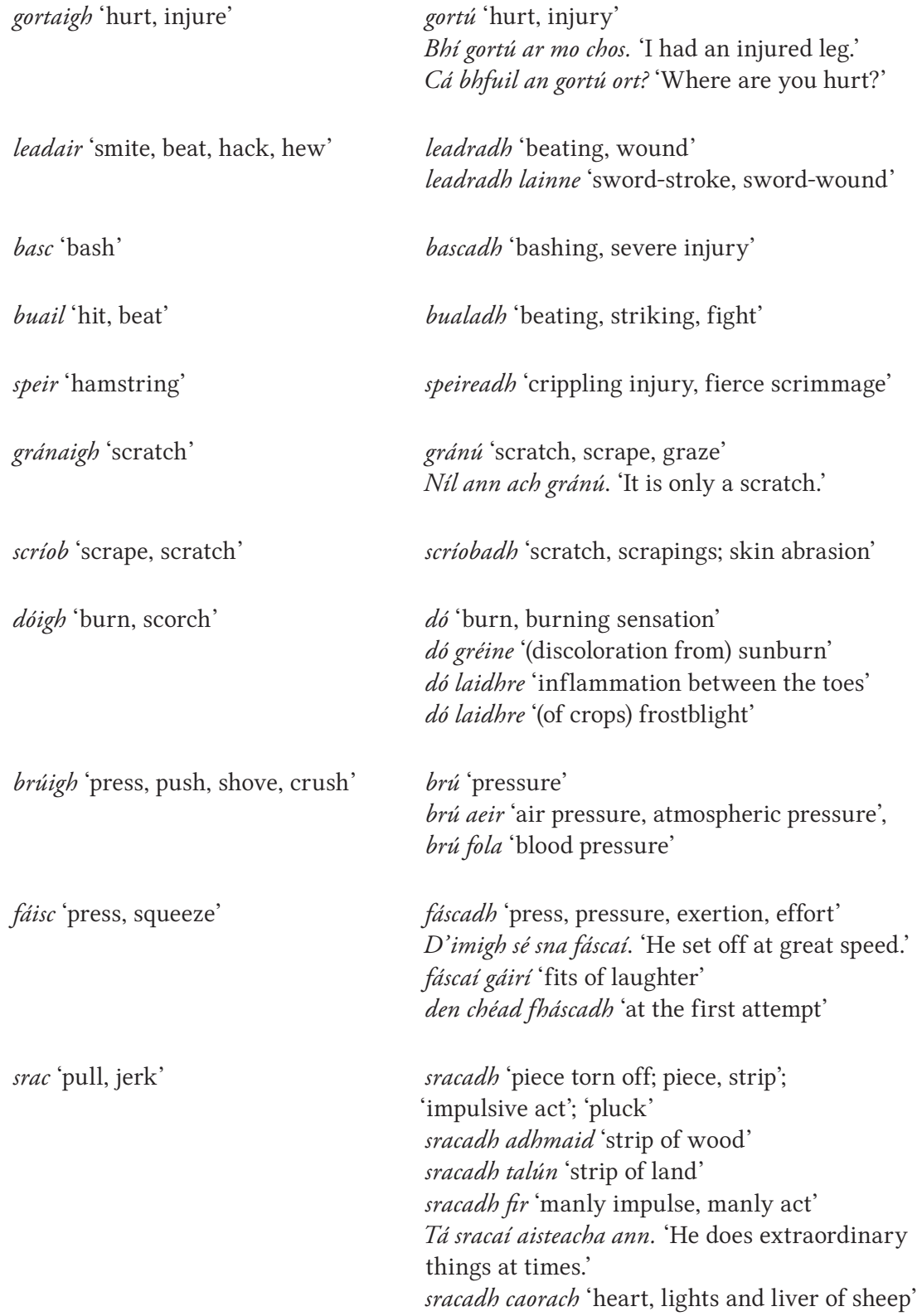

gortaigh 'hurt, injure'

leadair 'smite, beat, hack, hew'

basc 'bash'

buail 'hit, beat'

speir 'hamstring'

gránaigh 'scratch'

scriob 'scrape, scratch'

dóigh 'burn, scorch'

brúigh 'press, push, shove, crush'

fáisc 'press, squeeze'

srac 'pull, jerk'

gortú 'hurt, injury'

Bhi gortú ar mo chos. 'I had an injured leg.'

Cá bhfuil an gortú ort? 'Where are you hurt?'

leadradh 'beating, wound'

leadradh lainne 'sword-stroke, sword-wound'

bascadh 'bashing, severe injury'

bualadh 'beating, striking, fight'

speireadh 'crippling injury, fierce scrimmage'

gránú 'scratch, scrape, graze'

Nil ann ach gránú. 'It is only a scratch.'

scriobadh 'scratch, scrapings; skin abrasion'

dó 'burn, burning sensation'

dó gréine '(discoloration from) sunburn'

dó laidhre 'inflammation between the toes'

dó laidhre '(of crops) frostblight'

brú 'pressure'

brú aeir 'air pressure, atmospheric pressure',

brú fola 'blood pressure'

fáscadh 'press, pressure, exertion, effort'

D’imigh sé sna fáscai. 'He set off at great speed.'

fáscai gáiri 'fits of laughter'

den chéad fháscadh 'at the first attempt'

sracadh 'piece torn off; piece, strip';

'impulsive act'; 'pluck'

sracadh adhmaid 'strip of wood'

sracadh talun 'strip of land'

sracadh fir 'manly impulse, manly act'

Tá sracai aisteacha ann. 'He does extraordinary

things at times.'

sracadh caorach 'heart, lights and liver of sheep'

As expected, pure contact verbs such as caress or touch, which cannot be associated with a visible trace or mark on the patient, do not give rise to nominals with R-interpretations. This is the case with cuimilt 'rub, stroke.VN', sliocadh 'stroke.VN', cioradh 'comb.VN' and muirniú 'fondle, caress.VN'. In addition to this, if the verb lexicalizes a series of iterated atomic events (flail, trounce, 
pummel), an R-interpretation is not attested, even though there may be marks left on the Patient. This is true of giolcadh, sciuradh 'cane.VN', greadadh, greasáil, leasú, liuradh, rúscadh, stánáil 'beat, trounce.VN', ciorláil 'tousle.VN', radach 'pelt.VN' and lascadh 'lash, whip, flog.VN'. No product interpretation is available even for forms which can pluralize, such as flipeáil 'flip, strike; beat severely.VN' and súisteáil 'flail, thresh.VN'. There are no R-nominals with verbs whose theta grid contains an Agent and Patient (Recipient or Beneficiary). Consequently, nominals which denote verbs of social interaction are confined to the actional/eventive interpretation, e.g. cuidiu, cunamh, fóirithint, fortacht 'help.VN', cuimilt, sciúradh, scrabhadh 'scold.VN', feannadh 'criticize' and raiceáil 'maltreat.VN'.

Consumption/destruction verbs such as squander, waste, destroy, drink, consume and eat are semantic opposites of creation verbs. The internal arguments are incrementally affected by the gradual change induced by the event. Melloni (2011:228) explains that "the state resulting from the completion of the event implies the complete removal of the object; consequently, when the action is accomplished there is nothing left for the R-nominal to denote". Since there is no effected object, there can be no R-nominal with a product reading. This generalization holds for the majority of verbal nouns falling into this category: diomailt 'waste.VN', meilt 'chew, eat.VN', cnai 'gnaw, corrode.VN', seargadh 'waste, wither.VN', pléascadh 'explode.VN', scriosadh, diothú 'destroy.VN', milleadh 'spoil.VN', idiú 'use up.VN', ithe 'eat.VN', lea' 'melt.VN', galú 'vaporize.VN', marú 'kill.VN', cealú 'cancel.VN' (cf. cealúchán 'cancellation') and dreo 'decay.VN'.

R-nominals related to verbs of this category are few and far between. They denote an entity resulting from the destruction event. Jackendoff (1990) observes that destruction verbs could be interpreted as creation verbs. The only exception seems to be the verb ól 'drink', which takes an incremental affected object, and it is this object that is bound in the derivation of lexical meaning:

Table 5. R-nominals with a product interpretation related to verbs of destruction and consumption

$$
\text { Verb Nominalization (plural) }
$$

raiceáil 'wreck'

goid 'take away, remove, steal' raiceáil 'wrecking, wreck' raiceáil loinge 'the wreck of a ship'

goid 'thing stolen' goid a ithe 'to eat stolen food' 
cart 'clear away'

ól 'drink' cartadh 'cleared-out material'

ól 'drink, drinking-liquid'

Is milis an t-ól é. 'It is a sweet drink.'

\subsection{Non-prototypical creation verbs}

In this section we will examine the potential for forming R-nominals in verbs which can be classified as non-prototypical creation verbs. Non-prototypical creation verbs include cooking verbs, verbs of assembling, speech act verbs, mental action verbs and verbs of emission.

Cooking verbs can acquire the function of verbs of creation and their corresponding nominals may show the object interpretation, as in róst 'roast' - róstadh 'roasting, roast' and grioll 'grill, broil'-griolladh 'broil, broiled meat'. However, no R-interpretations are available to fiuchadh, bruith 'boil.VN', cócaráil 'cook.VN' and bácáil 'bake.VN', so the evidence from this category is inconclusive.

Semantically, verbs of assembling and combining describe situations of assembling/grouping/associating of animate and inanimate entities and imply the gradual coming into existence of a resulting entity. Therefore, they are potential candidates for the product R-interpretation, as corroborated by the data in Table 6 below.

\section{Table 6. R-nominals with a product interpretation related to verbs of assembling and combining}

\section{Verb}

diolaim 'glean, gather, collect, compile'

cruinnigh 'gather, assemble'

bailigh 'collect, gather'

cnuasaigh 'gather food (from woodland, sea-shore), pick (potatoes, etc.), collect, store'

\section{Nominalization (plural)}

diolaim 'collection, compilation' diolaim dána 'anthology of verse'

cruinniú 'gathering, assemblage'; '(needlework) pucker, gather' cruinniu daoine 'a gathering of people' cruinnithe a chur in éadach 'to pucker cloth'

bailiú 'collection, accumulation', bailiú daoine 'gathering, assembly'

cnuasach 'garnered food'; 'collection' cnuasach coille 'gleanings of woodland' cnuasach trá 'gleanings of seashore' cnuasach mara agus tire 'food gathered from sea and land' 
tacair 'glean, gather'

saothraigh 'earn'

fiach 'hunt, chase'

seilg 'hunt, chase' tacar 'set'

tacar iata closed set',

tacar iomlán 'complete set'

tacair scartha 'disjoint sets'

saothrú 'earnings, wages'

Tá saothrú maith aige. 'He has good

earnings.'

fiach 'game'

fiach a fháil 'to find game'

seilg 'game, prey, quarry'

an tseilg a thabhairt isteach 'to bring home

the quarry',

seilg an lae 'the day's catch (of fish, etc.)'

There is no R-interpretation available for carn 'heap, pile.VN', eagrü 'arrange. VN' (cf. eagraiocht 'organization') and meascadh 'mix.VN' (cf. meascán 'mixture').

Speech act verbs, verbs of communication and of the transfer of ideas, in overwhelming majority give rise to nominals with referential readings. ${ }^{9}$ These verbs take the Agent and the internal argument, which is a proposition expressed by an embedded clause, PP or a DP. Such a proposition can be interpreted as the speech artefact which is created through the accomplishment of the speech event. Being information objects, such nominals can give rise to metonymic displacements where abstract content is viewed as a concrete manifestation (a statement can be oral or written).

Table 7. R-nominals with a product interpretation relatd to speech act verbs, verbs of communication and of the transfer of ideas

\section{Verb \\ Nominalization (plural)}

abair 'say, utter, speak'

luaigh 'mention, cite' rá 'saying, utterance'

rá Bhearcháin 'Bearchan's saying, prophecy'

ráite béil 'statements, remarks'

lua 'mention, citation, reference'

lua foinse 'reference to source'

9. The following were found to be confined to the actional interpretation: fógairt 'call out, proclaim.VN', aontú 'assent, agree.VN', beannú 'bless.VN' (cf. beannacht) and cúiseamh 'accuse.VN'. 
maigh 'state, declare'

admhaigh 'acknowledge'

deimhnigh 'certify; affirm, assure'

dearbhaigh 'declare, affirm, assure'

mol 'praise, commend'

fianaigh 'attest, testify'

gearán 'complain'

tagair 'allude'

trácht 'mention'

fiafraigh 'ask'

iomardaigh 'reproach'

tairg 'offer'

tairngir 'prophesy'

tuar 'prophesy'

conspóid 'argue'

impigh 'entreat'

diotáil 'indict' maiomh 'statement, assertion'

admháil 'acknowledgement, admission'; 'receipt' admháil creidimh 'profession of faith'

foirm admhála 'receipt-form'

deimhniú 'certification, certificate, affirmation', deimhniú cáiliochta 'certificate of qualification' deimhniú inniúlachta 'certificate of competence'

dearbhú 'declaration; affirmation; confirmation'

moladh 'praise'; 'eulogy, panegyric'

moladh mairbh 'panegyric for deceased person', moltai 'lauds'

fianú 'attestation'

gearán 'complaint, grievance'

tagairt 'reference, allusion'

trácht 'mention (of)'; 'discourse'; 'comment'

fiafrai 'inquiry, question',

Cén a fiafraithe sin ort? 'Why all these questions?'

iomardú 'reproach, accusation, challenge'

tairiscint 'offer, bid'

tairngreacht 'prediction, prophecy'

tuar 'sign, omen'

tuar cogaidh 'portent of war'

tuar tubaiste 'foreboding of tragedy'

conspóid 'argument, dispute, controversy'

impí 'entreaty, intercession'

Déanaim impi 'I supplicate.'

diotáil 'indictment' 
éiligh 'claim, demand'

socraigh 'agree, arrange'

bagair 'utter a threat'

éar 'refuse, deny, repel'

eitigh 'refuse'

ordaigh 'order'

meil 'talk, discuss, incessantly' éileamb 'claim, demand'

élimh ainmheasartha 'unreasonable demands'

socru' 'settlement, arrangement, agreement'

socruithe sochraide 'funeral arrangements'

bagairt 'threat'

bagairti a spalpadh 'to thunder out threats'

éaradh 'refusal, denial'

eiteach 'refusal'

eiteach dearg 'a flat refusal'

ordú 'order, command, injunction'

orduithe máirseála 'marching orders'

meilt 'incessant talk'

Activity verbs which denote dynamic situations of the emission of light, sound and substances can give rise to an R-nominal, which refers to the emitted entity and so can be viewed as an effected object. Again, it has to be stressed that verbs belonging to this class do not satisfy the requirements of effectedness and incrementality put forward by Melloni (2011).

\section{Table 8. R-nominals with a product interpretation related to verbs of emission}

\begin{tabular}{|c|c|}
\hline Verb & Nominalization (plural) \\
\hline astaigh 'emit' & astú 'emission' \\
\hline tál '(of milk) field, shed, pour, secrete' & $\begin{array}{l}\text { tál 'lactation'; 'yield, flow' } \\
\text { tál breá bainne 'good yield of milk' } \\
\text { tál deor 'flow of tears' }\end{array}$ \\
\hline gleadhair 'beat noisily, pelt, pummel' & $\begin{array}{l}\text { gleadhradh 'noisy beating, clatter'; 'blaze, } \\
\text { flare, glare' } \\
\text { gleadhradh cos ar an urlar 'clatter of feet on } \\
\text { the floor' } \\
\text { gleadhradh cainte 'din of talk' } \\
\text { gleadhradh tine 'blazing fire' } \\
\text { gleadhradh solais 'glare of light' }\end{array}$ \\
\hline
\end{tabular}




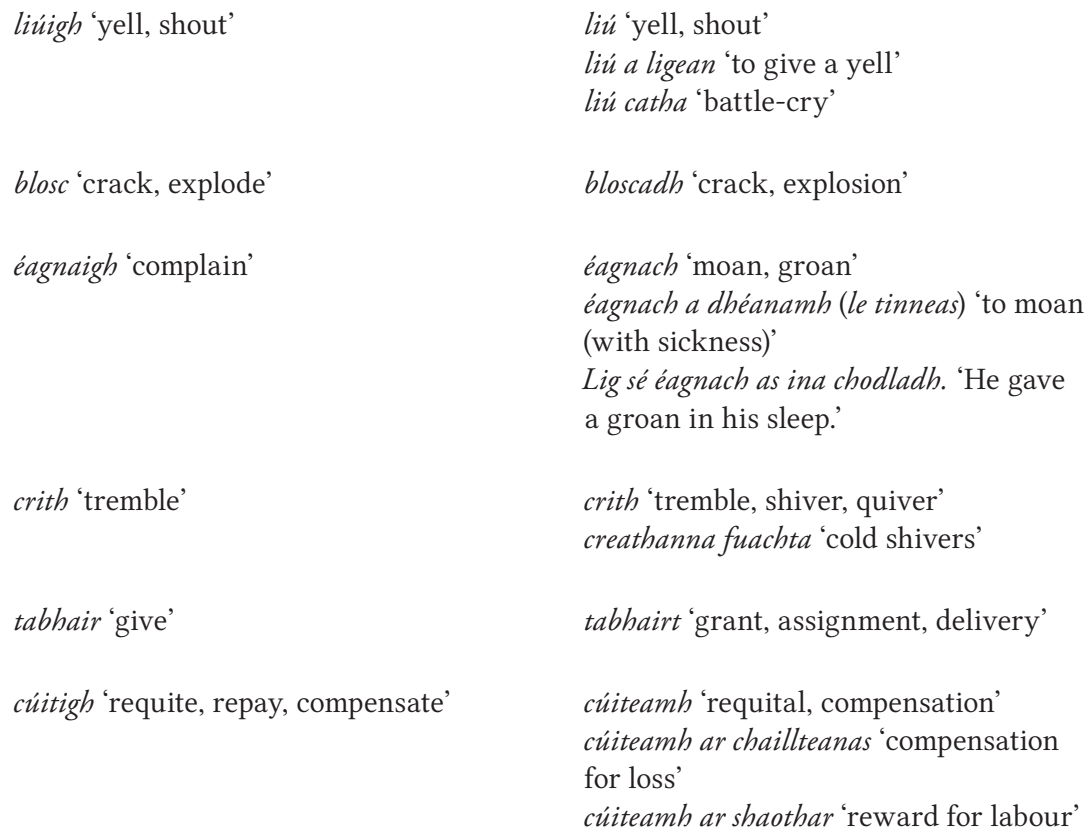

liúigh 'yell, shout'

éagnaigh 'complain'

crith 'tremble'

cúitigh 'requite, repay, compensate'

liú 'yell, shout'

liú a ligean 'to give a yell'

liú catha 'battle-cry'

bloscadh 'crack, explosion'

éagnach 'moan, groan' éagnach a dhéanamh (le tinneas) 'to moan (with sickness)'

Lig sé éagnach as ina chodladh. 'He gave a groan in his sleep.'

crith 'tremble, shiver, quiver' creathanna fuachta 'cold shivers'

tabhairt 'grant, assignment, delivery'

cúiteamh 'requital, compensation' cúiteamh ar chaillteanas 'compensation for loss'

cúiteamh ar shaothar 'reward for labour'

However, we do not observe a product interpretation in dioscadh 'creak, grate.VN', brúchtadh 'belch, burst, erupt.VN', ligean 'release.VN' and sceitheadh 'pour forth, discharge, erupt.VN'.

Directed motion verbs such as climb and go down indicate a change in location along a directed, spatial Path. Dowty (1991) argues that they have holistic (non-incremental) Themes. However, directed motion verbs are likely to show the non-eventive meaning - the directed Path covered by the moving entity (which is a Theme). Stative verbs with a degree interpretation will give rise to the measure reading. I have found only a handful of examples which illustrate this regularity:

Table 9. R-nominals with a product interpretation related to verbs with degree interpretation

$$
\text { Verb Nominalization (plural) }
$$

tit 'fall'

tarraing 'pull, haul' titim 'fall'

titim aille 'slope of cliff'

tarraingt 'drag, haul, haulage, traction' tarraingt cloch 'haulage of stones'

Is fada an tarraingt é. 'It is a long haul.' 
tuirling 'descend, land'

slog 'swallow, gulp down'

lig 'let, release, extend'

croch 'hang, raise up, lift' tuirlingt 'descent, landing'

slogadh 'swallow'

Táslogadh fada aige. 'He takes a long draught (has a large capacity for drink).'

ligean 'scope, stretch, extension' ligean sciathán 'wing-stretch measure'

crochadh 'pitch, amount of slope' crochadh áirse 'the pitch of an arch' crochadh din 'the pitch of an roof'

\subsection{Activities and states}

We now turn to the overview of verb classes which in Melloni's (2011) analysis are not expected to give rise to R-nominals on account of their inherent aspectual and semantic characteristics.

Activity verbs should not produce results, neither effected objects nor modifications. Since they lack an incremental Path component of meaning they cannot display a path reading either. This prediction is corroborated by the Irish data. The following verbal nominalizations related to activity verbs do not have entity denotations: rómbar, tochailt 'dig.VN', foghlaim 'learn. $\mathrm{VN}$, taighde 'research.VN', scuabadh 'sweep.VN', iascach 'fish.VN', rialú 'rule, govern.VN' (cf. rialuichán 'regulation, control', rialtas 'government'), stiurradh 'steer.VN', riar 'administer, manage.VN' (cf. riarachán 'administration') and fanacht 'wait.VN'.

Mental action verbs relate to the opinion or judgement somebody may have in reaction to something. They are usually classified as states with a proposition or a cognate object as an internal argument. If attested at all, ${ }^{10}$ a corresponding R-nominal expresses the abstract content of a proposition, as in (19) below:

10. The nominalizations confined to the regular interpretation far outnumber those with resultative semantics: ceapadh, sileadh 'think, consider.VN', meas 'estimate, consider.VN', breathnu 'observe, examine, judge.VN', samblú 'imagine.VN' and réasúnú, meabhrú 'reason.VN'. 
(19)

\begin{tabular}{|c|c|}
\hline Verb & Nominalization (plural) \\
\hline smaoinigh 'think, reflect, consider' & $\begin{array}{l}\text { smaoineamh 'thought, reflection, idea' } \\
\text { smaointe casta ar chursai an tsaoil 'complicated } \\
\text { thoughts on the affairs of life' }\end{array}$ \\
\hline baruil 'think, be of the opinion (that)' & barúil 'opinion' \\
\hline measúnaigh 'assess' & measúnú 'assessment' \\
\hline
\end{tabular}

State verbs, which describe non-dynamic situations, hardly ever give rise to R-nominals. R-nominals refer to the (animate and inanimate) entities associated with the states, e.g. teastaigh 'be wanted, needed' - teastálacha '(pl.) necessaries', as in teastálacha beaga a bhi uaim 'little things I needed'. With verbs which take a Subject Experiencer, the corresponding R-nominal can refer to the propositional content if the verb takes a subordinate clause or to the Source argument, e.g. meall 'beguile, deceive'-mealladh 'deception, disappointment', tnuth 'long for, desire'- tnuth 'expectation, desire'.

\section{Conclusion}

It is impossible to state the restrictions on the development of concrete senses in action nouns in absolute terms; i.e. we can only speak of tendencies. As rightly observed by Melloni (2001), it is not possible to predict the polysemy of nominals only on the basis of their event-structure properties. Reference has to be made to deeper levels of their semantics (be it qualia structure in the model of Pustejovsky (1995) or Body in the model of Lieber (2004)).

We started our discussion by separating cases of inherent polysemy from context-dependent meanings, sense extensions and lexicalizations. We have observed that action nouns in Irish can give rise to manner and ability interpretations depending on the type of superordinate predicate. However, unlike verbal nouns in many other languages, they do not show the factual interpretation and the temporal reading is infrequent. In terms of sense extensions, action nouns can undergo metonymic transfer to denote locations and inanimate instruments but not animate collections.

In this paper we have managed to identify several regularities pertaining to the emergence of result interpretations, which in Melloni's terms can be viewed as product, object, means or entity in state. Melloni's claim that R-nominals bear the feature [-dynamic] and cannot denote Agents or Instruments, i.e. LCS participants agentively involved in dynamic situations, 
finds support in the Irish data. R-nominals assume the function of some other LCS participant in the situation. In many cases it is the effected object/Theme which comes into existence as a result of an incremental activity. Therefore, broadly understood, verbs of creation give rise to product readings. These include verbs of creation, representation and modification. R-nominals related to verbs of creation are not as numerous as expected on account of semantic blocking. Non-prototypical creation verbs relating to assembling deserve to be mentioned in this respect, unlike for example degree achievements.

In the course of our analysis it has transpired that verbs, which need not satisfy the requirements of effectedness and incrementality are equally, or even more, important. Verbs of damage, contact by impact and exerting force, which in aspectual terms need not be classified as transitions and which take affected rather than effected objects, can give rise to product interpretations in R-nominals.

Another prominent class which almost always gives rise to R-nominals consists of verbs relating to speech acts, communication and transfer of information. They denote the contents of the proposition which acts as the complement of the verb. In addition, activity verbs which relate to emission, understood in a broad way, can form R-nominals since the activity brings about effects/by-products in the form of emitted substances, sounds, movements, etc.

Directed motion verbs and verbs of consumption which have an incremental argument have an $\mathrm{R}$ interpretation corresponding to the path. Manner of motion verbs which lack an incremental path are excluded as sources for R-nominals. Nevertheless, such nouns are attested.

Due to the fact that the inventory of stative verbs in Irish is impoverished compared to other languages, the evidence relating to verbs expressing mental or psychological states, spatial configuration and propositional attitude is inconclusive and must be left for future research.

The John Paul II Catholic University of Lublin 


\section{References}

Alexiadou, A., 2001, Functional Structure in Nominals. Nominalization and Ergativity, Amsterdam.

Anderson, M., 1984, 'Prenominal Genitive NPs', The Linguistic Review 3, 1-24. Beard, R., 1987, 'Lexical Stock Expansion', in: Gussmann, E., ed., Rules and the Lexicon. Studies in Word Formation, Lublin, 23-42.

Bierwisch, M., 1991, 'Event Nominalizations. Proposals and Problems', Acta Linguistica Hungarica 40 (1-2), 19-84.

Booij, G. \& Lieber, R., 2004, 'On the Paradigmatic Nature of Affixal Semantics in English and Dutch', Linguistics 42, 327-57.

Borer, H., 2003, 'Exo-skeletal vs. Endo-skeletal Explanations. Syntactic Projections and the Lexicon', in: Moore, J. \& Polinsky, M., eds., The Nature of Explanation in Linguistic Theory, Stanford, CA, 31-67.

Carstairs-McCarthy, A., 1992, Current Morphology, London and New York. Comrie, B., 1976, 'The Syntax of Action Nominals. A Cross-language Study', Lingua 40, 177-202.

Comrie, B., \& Thompson, S. E., 1985, 'Lexical Nominalizations', in: Shopen, T., ed., Language Typology and Syntactic Description, Cambridge, 349-96.

de Bhaldraithe, T., 1959, English-Irish Dictionary, Dublin.

Dowty, D., 1976, Word Meaning and Montague Grammar. The Semantics of Verbs and Times in Generative Semantics and in Montague's PTQ, Dordrecht.

Dowty, D., 1991, 'Thematic Proto-roles and Argument Selection', Language 67, 547-619.

Doyle, A., 2002, Covert and Overt Pronominals in Irish, Lublin.

Grimshaw, J., 1990, Argument Structure, Cambridge.

Hay, J., Kennedy, C., \& Levin, B., 1999, 'Scalar Structure Underlies Telicity in Degree Achievement', in: Matthews, T., \& Strolovitch, D., eds., The Proceedings of SALT IX, Ithaca, 127-44.

Jackendoff, R. S., 1990, Semantic Structures, Cambridge.

Kastovsky, D., 1986, 'The Problem of Productivity in Word Formation', Linguistics 24, 585-600.

Koptjevskaja-Tamm, M., 1993, Nominalizations, London.

Langacker, R., 1991, Foundations of Cognitive Grammar, Vol. II. Descriptive Application, Stanford.

Lieber, R., 2004, Morphology and Lexical Semantics, Chicago.

Malicka-Kleparska, A., 1988, Rules and Lexicalisations. Selected English Nominals, Lublin.

Marchand, H., 1969, The Categories and Types of Present-Day English WordFormation. A Synchronic-Diachronic Approach, München. 
Melloni, Ch., 2011, Event and Result Nominals. A Morphosemantic Approach, Bern. Melloni, Ch., \& Ježek, E., fc., 'Complex Types in the (Morphologically) Complex Lexicon', in: Bouillon, P., ed., Proceedings of the GL2009, 5th International Conference on Generative Approaches to the Lexicon, Sept.15-17, Pisa, Italy (available at http://attach.matita.net/elisabettajezek/file/Jezek-Melloni-GL2009.pdf) [last accessed 09.02.2017].

New English-Irish Dictionary (available at http://www.focloir.ie/en/).

Ó Dónaill, N., 1977, Foclóir Gaeilge-Béarla [Irish-English dictionary], Dublin. Pustejovsky, J., \& Anick, P., 1988, 'On the Semantic Interpretation of Nominals', in: Vargha, D., ed., Proceedings of the 12th Conference on Computational Linguistics. Vol. 2, Budapest, 518-23.

Pustejovsky, J., 1995. The Generative Lexicon, Cambridge, MA.

Pustejovsky, J., 2005. 'A Survey of Dot Objects', Brandeis University (available at http: //www.cs.brandeis.edu/ jamesp/dots.pdf/) [last accessed 09.02.2017]. Rozwadowska, B., 1997, Towards a Unified Theory of Nominalizations. External and Internal Eventualities, Wrocław.

Tenny, C., 1994, Aspectual Roles and the Syntax-Semantics Interface, Dordrecht. Walińska de Hackbeil, H., 1984, 'On Two Types of Derived Nominals', in: Testen, D., Mishra,V., \& Drogo, J., eds., Papers from the Parasession on Lexical Semantics, Chicago, 308-32.

Vendler, Z., 1967, Linguistics in Philosophy, New York. 
